\title{
Cluster Node
}

National Cancer Institute

\section{Source}

National Cancer Institute. Cluster Node. NCI Thesaurus. Code C44475.

An individual component of a clustering. May contain other nodes. 